\title{
PENERAPAN MODEL KONSTRUKTIVISME UNTUKMENINGKATKAN BERPIKIR KRITIS SISWA PADA MATAPELAJARAN IPS DI KELAS V SDN 18 TUBUNG
}

\author{
Sepiana Rosita ${ }^{1}$,Asep Eka Nugraha ${ }^{2}$, Ahmad Khoiri ${ }^{3}$ \\ ${ }^{1}$ Mahasiswa Lulusan Program Studi PGSD \\ ${ }^{2,3}$ Dosen STKIP Melawi \\ Jl. RSUD Melawi km. 04 Kec.Nanga Pinoh Kab. Melawi Kalimantan Barat \\ Email : Sepianarosita97@gmail.com, Asepekanugraha81@gmail.com,
}

Ahmadkhoiri2290@gmail.com

\begin{abstract}
The general purpose of the research is to improve students' critical thinking by applying constructivism models in social studies learning on the material events of the arrival of westerners in class V of Elementary School Public 18 Tubung. The purpose of the research is specifically to improve (1) Planning learning by using constructivism models on social studies subjects to improve students' critical thinking (2) Implementation of learning by using constructivism models on social studies subjects to improve students' critical thinking (3) Students' critical thinking results by using the constructivism model on social studies subjects.This study used the classroom action research method, with the type of participant research. The research design uses the Kemmis and Mc Taggart models, namely planning, implementation, observation, reflection. The research instruments used were observation sheets for learning planning and implementation of learning, student observation sheets and student worksheets. The number of subjects in this study were 14 students consisting of 7 male students and 7 female students.The results showed: (1) The ability of teachers to plan learning increased to 0,19 from the average value of the first cycle of 3.38 while the second cycle of 3,57. (2) The ability of teachers in implementing learning shows an increase of 0,29 from the average value of the first cycle of 3,28 while the second cycle of 3,57. (3) The results of students' critical thinking also increased by 18,30 , from the average value of the first cycle which is 62,50 while the second cycle of 80,80 . Judging from the completeness value of student learning outcomes with Minimum Mastery Criteria (KKM) which is 60, in the first cycle the average value of 67,57 and the second cycle of 77,85 means that social studies learning material on the event of the arrival of the western nation has been declared complete has reached minimum completeness criteria, by applying constructivism learning models to social studies subjects about western events, students' critical thinking increases.
\end{abstract}

Keywords: Application, Constructivism Model, Critical Thinking of Students, Social Sciences Subjects

\begin{abstract}
Abstrak: Tujuan penelitian secara umum yaitu meningkatkan berpikir kritis siswa dengan menerapkan model konstruktivisme dalam pembelajaran IPS pada materi peristiwa kedatangan bangsa barat di kelas V SD Negeri 18 Tubung. Adapun tujuan penelitian secara khusus yaitu meningkatkan(1) Perencanaan pembelajaran dengan menggunakan model konstruktivisme pada mata pelajaran IPS untuk meningkatkan berpikir kritis siswa (2) Pelaksanaan pembelajaran dengan menggunakan model konstruktivisme pada mata pelajaran IPS untuk meningkatkan berpikir kritis siswa (3) Hasil berpikir kritis siswa dengan menggunakan model konstruktivisme pada mata pelajaran IPS.Penelitian ini menggunakan metode Penelitian Tindakan Kelas, dengan jenis penelitian partisipan. Desain penelitian menggunakanmodel Kemmis dan Mc Taggart yaitu perencanaan, tindakan/pelaksanaan, pengamatan, refleksi. Instrumen penelitian yang digunakan yaitu lembar observasi perencanaan pembelajaran dan pelaksanaan pembelajaran, lembar observasi siswa dan lembar kerja siswa. Jumlah
\end{abstract}

J P D , p - I S S N : 2252 - 8156 , e - I S S N : 2579 - 3993 
subjek pada penelitian ini 14 siswa terdiri 7 siswa laki-laki dan 7 siswa perempuan.Hasilpenelitian menunjukan: (1) Kemampuan guru dalam merencanakan pembelajaran meningkat menjadi 0,19 dari nilai rata-rata siklus I 3,38 sedangkan siklus II 3,57. (2) Kemampuan guru dalam pelaksanaan pembelajaran menunjukan peningkatan 0,29 dari nilai rata-rata siklus I 3,28 sedangkan siklus II 3,57. (3) Hasil berpikir kritis siswa juga meningkat 18,30, dari nilai rata-rata siklus I yaitu 62,50 sedangkan siklus II80,80. Dilihat dari nilai ketuntasan hasil belajar siswa dengan Kriteria Ketuntasan Minimum (KKM) yaitu 60, pada siklus I nilai rata-rata 67,57 dan siklus II77,85 artinya pembelajaran IPS pada materi peristiwa kedatangan bangsa barat dinyatakan tuntas telah mencapai kriteria ketuntasan minimum, dengan menerapkan model pembelajaran konstruktivisme pada mata pelajaran IPS tentang peristiwa bangsa barat maka berpikir kritis siswa meningkat.

Kata Kunci: Penerapan, Model Konstruktivisme,Berpikir Kritis Siswa, MataPelajaran Ilmu Pengetahuan Sosial

Doses belajar di kelas sangat
berpengaruh pada suatu tujuan yang ingin dicapai oleh seorang guru, pada dasarnya proses belajar yang baik tidak hanya di peroleh dari guru yang berperan aktif. Dalam proses belajar siswa juga dituntu dapat berkomunikasi mengenai materi yang di sampaikan oleh guru baik itu berupa pertanyaan, menjawab atau memberikan pendapat. Berpikir kritis dapat mendorong siswa untuk mengeluarkan ide baru. Pembelajaran keterampilan berpikir kritis kadang-kadang dikaitkan dengan keterampilan berpikir kreatif Sapriya (2017:87). Berpikir kritis merupakan salah satu cara untuk melatih siswa dalam pembelajaran termaksud dalam pembelajaran peristiwa kebangsaan masa penjajahan. Dengan berpikir kritis siswa dituntut untuk memahami serta mempelajari peristiwa kebangsaan masa penjajahan dengan benar, sehingga pengetahuan siswa berkembang dan tidak hanya terpaku pada penjelasan yang diberikan oleh guru dan buku sumber yang dimiliki siswa.

Pada dasarnya Ilmu Pengetahuan Sosial (IPS) merupakan salah satu mata pelajaran yang ada di sekolah dasar. Setiap mata pelajaran memiliki ruang lingkup yang berbeda-beda. Ruang lingkup dalam pembelajaran dapat dijadikan sebagai pembatas dalam menyampaikan materi pembelajaran. IPS mempelajari, menelaah, dan mengkaji sistem kehidupan manusia di permukaan bumi ini dalam konteks sosial atau manusia sebagai anggota masyarakat. Pembelajaran IPS di sekolah dasar menurut Susanto (2013:138) adalah memberikan pengetahuan dan keterampilan dasar yang berguna bagi dirinya dalam kehidupan sehari-hari. Pelaksanaan proses pembelajaran IPS yang dilaksanakan di sekolah dasar mempunyai peranan untuk mempersiapkan siswa memperoleh bekal pengetahuan mengenai konsep kehidupan masyarakat dan lingkungan serta memperoleh keterampilan dasar dalam 
menerapkannya bersama dengan pengetahuan tersebut.

Berdasarkan hasil pra siklus yang telah di lakukan di Sekolah Dasar Negeri 18 Tubung data yang diperoleh dari hasil belajar siswa Ilmu Pengetahuan Sosial (IPS) menunjukan sebagai berikut: siswa yang mencapai nilai 77 sebanyak 1 siswa, 72 sebanyak 2 siswa, 61 sebanyak 3 siswa, 55 sebanyak 4 siswa, 50 sebanyak 1 siswa, 38 sebanyak 1 siswa, 33 sebanyak 2 siswa dengan mencapai rata-rata 55,57. Sedangkan KKM 60, hasil belajar siswa menunjukkan dibawah KKM. Selanjutnya berdasarkan data yang diperoleh dari alat penilaian kemampuan guru dalam aspek perencanaan pembelajaran dengan nilai 3,23 dikatakan cukup, sedangkan perolehan dan alat penilaian kemampuan guru dalam aspek pelaksanaan pembelajaran dengan nilai 2,58 dikatakan kurang, dari data perencanaan pembelajaran dan pelaksanaan pembelajaran menunjukan masih perlu ditingkatkan. Adapun permasalahan yang timbul pada guru dalam proses pembelajaran yaitu dalam menggunakan media dan model kurang bervariasi. Selanjutnya masalah yang timbul dalam pembelajaran yang dilakukan oleh siswa, yaitu (1) ketika guru menjelaskan materi hanya beberapa siswa yang memperhatikan karena siswa sibuk bermain atau ngomong dengan teman sebangkunya. (2) guru memberikan pertanyaan kepada siswa, 40| J P D , p-IS S N : 2252-8156, tetapi hanya beberapa siswa aktif yang mampu menjawab. (3) siswa lebih cenderung teks book ketika menjawab berbagai pertanyaan yang disampaikan guru.

Dari permasalahan di temukan, sehingga menimbulkan pertanyaan yaitu "bagaimana cara membuat berpikir kritis siswa meningkat ?" dari pertanyaan ini menjadi solusi yaitu dengan menggunakan model konstruktivisme. Model konstruktivisme dipandang tepat untuk mengatasi persoalan dalam kegiatan pembelajaran IPS tentang peristiwa kedatangan bangsa barat. Model Konstruktivisme adalah suatu model yang menekankan pentingnya siswa membangun sendiri pengetahuan mereka lewat keterlibatan aktif dalam proses belajar mengajar menurut Mahdatika (Trianto 2011:106).

Dari hasil pra siklus yang telah di paparkan di atas bahwa penerapan model konstruktivisme dapat meningkatkan berpikir kritis siswa dan dapat meningkatkan hasil belajar siswa dalam pembelajaran IPS tentang peristiwa kedatangan bangsa barat. Berdasarkan latar belakang bahwa penggunaan model pembelajaran konstruktivisme, dapat meningkatkan berpikir kritis siswa dari hal tersebut perlu melakukan Penelitan Tindakan Kelas di kelas V SDN 18 Tubung Kecamatan Belimbing Kabupaten Melawi - I S S N : 2579 - 3993 
dengan judul "Penerapan Model konstruktivisme untuk Meningkatkan Berpikir Kritis IPS Siswa Kelas V SDN 18 Tubung".

Pada penelitian ini masalah dibatasipada kurangnya kemampuan berpikir kritis siswa dalam pembalajaran IPS.Rumusan secara umum yaitu apakah penerapan model konstruktivisme dapat meningkatkan berpikir kritis siswa pada pembelajaran IPS tentang peristiwa kedatangan bangsa barat ?. Sedangkan rumusan masalah secara khusus diuraikan sebagai berikut (1) Bagaimana perencanaan pembelajaran dengan menggunakan model konstruktivisme pada mata pelajaran IPS untuk meningkatkan berpikir kritis siswa kelas V SD Negeri 18 Tubung ? (2) Bagaimana pembelajaran dengan menggunakan model konstruktivisme pada mata pelajaran IPS untuk meningkatkan berpikir kritis siswa kelas V SD Negeri 18 Tubung ? (3) Bagaimana berpikir kritis siswa kelas V SD Negeri 18 Tubung dengan menggunakan model konstruktivisme pada mata pelajaran IPS ?

Tujuan secara umum yaitu untuk meningktkan berpikir kritis siswa dengan menerapkan model konstruktivisme dalam pembelajaran IPS pada materi peristiwa kedatangan bangsa barta di kelas V SD Negeri 18 Tubung. Adapun tujuan penelitian secara khusus yaitu sebagai berikut : (1) Meningkatkan perencanaan pembelajaran dengan menggunakan model konstruktivisme pada mata pelajaran IPS untuk meningkatkan berpikir kritis siswa kelas V SD Negeri 18 Tubung. (2) Meningkatkan pelaksanaan pembelajaran dengan menggunakan model konstruktivisme pada mata pelajaran IPS untuk meningkatkan berpikir kritis siswa kelas V SD Negeri 18 Tubung. (3) Meningkatkan hasil berpikir kritis siswa kelas V SD Negeri 18 Tubung dengan menggunakan model konstruktivisme pada mata pelajaran IPS.

\section{METODE PENELITIAN}

Penelitian ini di lakukan menggunakan Penelitian Tindakan Kelas. Penelitian Tindakan Kelas merupakan adalah penelitian yang dilakukan oleh guru di kelasnya sendiri melalui refleksi diri dengan tujuan untuk memperbaiki kinerjanya sehingga hasil belajar meningkat Aqib, dkk (2011:3).

Metode yang digunakan dalam penelitian ini yaitu penelitian tindakan kelas. Penelitian tindakan kelas yaitu penelitian kerja berulang atau siklus, sehingga diperoleh pembelajaran yang dapat membantu siswa dalam menyelesaikan masalah yang terjadi. Tujuan Penelitian Tindakan Kelas untuk menyelesaikan masalah melalui sebuah perbuatan nyata. Penelitian Tindakan Kelas dalam penelitian ini dimaksudkan untuk 
memperbaiki berpikir kritis IPS siswa kelas V terhadap pembelajaran Ilmu Pengetahuan Sosial.

Jenis penelitian yang digunakan adalah jenis penelitian partisipan. Jenis penelitian partisipan ini adalah peneliti memposisikan sebagai guru dan terlibat langsung selama proses penelitian dari awal sampai selesai. Penelitian partisipan menurut Fadliyati (Sumarto 2003:17) pengambilan atau keterlibatan orang atau masyarakat dengan cara memberikan dukungan (tenaga, pikiran maupun materi) dan tanggung jawabnya terhadap setiap keputusan yang telah diambil demi tercapainya tujuan yang telah ditentukan bersama. Penelitian tindakan kelas ini dilaksanakan di SDN 18 Tubung, Kecamatan Belimbing, Kabupaten Melawi.Sasaran dalam penelitian ini adalah siswa kelas V SDN 18 Tubung, dengan fokus penelitian pada penerapan model konstruktivismeuntuk meningkatkan berpikir kritis Ilmu Pengetahuan Sosial.

Model penelitian yang dipilih dan digunakan dalam penelitian ini adalah menggunakan model Kemmis dan Mc. Taggart yang terkenal dengan model spiral dan jenis penelitian yang digunakan dalam penelitian ini adalah penelitian tindakan kelas (classroom action research) dengan menggunakan model pembelajaran konstruktivisme dalam pelaksanaan pembelajaran IPS pada siswa kelas V SDN 18 Tubung.

Desain penelitian menggunakan model Penelitian Tindakan Kelas (PTK) dengan model Kemmis dan Mc Taggart. Menggunakan empat kemponen penelitian menurut Arikunto (2010:131-132), yaitu:

(1) Perencanaan (planning)

Tindakan/Pelaksanaan (acting)

Pengamatan (obeserving) (4) Refleksi (reflecting)

Penelitian Tindakan Kelas (PTK) pada gambar 1 yaitu melalui 4 tahap sebagai berikut : (1) Pada perencanaan pembelajaran berupa dokumen persiapan pembelajaran yang disebut secara kolaboratif antara guru dan peneliti Aqib, dkk (2011:267). Data perencanaan meliputi menyiapkan RRP, lembar observasi, model pembelajaran dan Metode pembelajaran, instrumen penelitian yang di siapkan yaitu menyiapkan RRP, APKG I, APKG II, lembar obeservasi, dan lembar kerja siswa. (2) Pada tahap pelaksanaan, peneliti bersama guru mata pelajaran IPS mendesain pembelajaran menggunakan model pembelajaran yang telah dirancangkan. Selama pembelajaran berlangsung, peneliti mengajar menggunkan RPP yang telah disusun dengan pertimbangan dari guru mata pelajaran IPS. (3) Observasi atau pengamatan merupakan suatu teknik atau cara pengumpulan data dengan mengadakan 42| J P D, p- I S S N : $2252-8156$, e - I S S N : 2579 - 3993 
pengamatan terhadap kegiatan yang diteliti. Tahap ini akan dilakukan bersamaan dengan saat pelaksanaan. Pengamatan dilakukan pada waktu tindakan sedang berjalan. Pada tahap ini, penelitian melakukan pengamatan dan mencatat semua hal yang diperlukan dan terjadi selama pelaksanaan tindakan berlangsung. Pengumpulan data dilakukan menggunakan format observasi penilaian yang telah disusun. (4) Refleksi dalam penelitian adalah untuk mengkaji apakah berpikir kritis siswa pada pelajara IPS meningkat, jika belum meningkat maka dapat memperbaiki semua kekurangan yang terjadi selama pelaksanaan pembelajaran. Jika hasil siklus pertama belum mencapai kriteria keberhasilan, maka diadakan perbaikan. Penelitian ini selanjutnya diterapkan pada siklus berikutnya.

Subjek pada penelitian yaitu siswa kelas V SDN 18 Tubung tahun pelajaran 2019/2020 dengan populasi dalam penelitian tindakan kelas ini adalah 14 siswa yang terdiri dari 7 siswa laki-laki dan 7 siswa perempuan.

Objek dalam penelitian ini meningkatan berpikir kritis siswa dalam pembelajaran IPS setalah diterapkannya model pembelajaran konstruktivisme.

Penelitian Tindakan Kelas (PTK) dilaksanakan pada semester 2 , tahun ajaran 2019/2020 yaitu pada bulan maret 2019 sampai selesai dan tempat penelitian di 43 | J P D, p-IS S N : 22 252-8156, e - I S S N : $2579-3993$
SDN 18 Tubung, Kecamatan Belimbing, Kabupaten Melawi.Untuk melaksanakan penelitian, peneliti menggunakan tahapan yaitu (1) Kegiatan awal (2) Pelaksanaan (3) Pelaksanaan tindakan (4) Observasi atau pengamatan (5) Refleksi.

Pengolahan data alat penilaian kinerja guru (APKG) pada penilaian perencanaan dan pelaksanaan pembelajaran (APKG I, II)pada aspek perencanaan, perencanaan pembelajaran menggunakan rumus sebagai berikut :

$$
\mathrm{R}=\frac{\text { aspek } \text { yang diperoleh }}{\text { aspek }}=\cdots
$$

\section{Keterangan $: R=$ rata-rata}

Pengolahan data hasil berpikir kritisuntuk mentukan kriteria keberhasilan kemampuan berpikir kritis secara klasikal menurut Purwoko (Purwanto 2010:102) sebagai berikut :

Persentase $=\frac{\text { jumlah yang minimal cukup kritis }}{\text { jumlah siswa }} \times$
$100 \%$
Pengolahan data tes hasil belajaruntuk menghitung nilai dan rata-rata nilai siswa, digunakan menurut (Purwanto 2014:207) sebagai berikut :

Rumus penilaian lembar kerja siswa

nilai
$=\frac{\text { skor yang diperoleh }}{\text { skor yang maksimum }}$
$\times 100$


Keterangan :

Skor perolehan : Jawaban yang diperoleh oleh siswa

Skor maksimum : Total atau jumlah skor

Indikator keberhasilan Alat Penilaian Kemampuan Guru (APKG I danAPKG II) apabila alat penilaian kemampuan guru pada aspek perencanaan pembelajaran dan pelaksanaan pembelajaran dikatakan berhasil jika memperoleh rata-rata minimal 3,50. Dengan tingkat penguasaan sebagai berikut :sangat terlaksana (A)3,51-4, terlaksana (B)2,51-3,50, cukup terlaksana (C)1,51-2,50,tidak terlaksana (D)1-1,50. peneliti membuat patokan klasikal kriteria keberhasilan dalam penelitian tindakan kelas ini apabila hasil belajar siswa sudah meningkat $80 \%$ (12 orang) dari 14 orang siswa telah mencapai target yang di harapkan yakni memperoleh kriteria di atas yaitu B maka peneliti dapat dikatakan berhasil dalam pelaksanakan Penelitian Tindakan Kelas (PTK).

Kriteria persentase keterlaksanaan tes kemampuan berpikir kritisdengan menghitung tingkat penguasaan berpikir kritis siswa diuraikan sebagai berikut: kritis sekali (A)81-100\%,kritis(B)66-80\%,cukup kritis (C)56-65\%,kurang kritis(D)41-55\%, tidak kritis(E)0-40\%. Indikator keberhasilan hasil observasi berpikir kritiskriteria keberhasilan dalam penelitian tindakan kelas ini apabila keberhasilan dalam berpikir kritis dikatakan berhasil jika 12 siswa atau lebih memperoleh kategori tinggi. Tingkat penguasaan berpikir kritis siswa dengan tategori tinggi 3-4 dan kategori rendah 1-2.

Taraf hasil belajar siswapenelitian ini dinyatakan berhasil jika berpikir kritis pada diri siswa meningkat. Apabila 12 dari 14 siswa mengalami peningkatan hasil belajar. Penelitian ini dinyatakan berhasil jika kriteria keberhasilan dalam penelitian tindakan kelas untuk objek yang di teliti apabila tingkat berpikir kritis siswa mengalami peningkatan diri tingkatan berpikir kritis.Untuk menghitung tingkat penguasaan hasil belajar siswa diuraikan sebagai berikut:Amat Baik (A) 86-100, Baik (B) 71-85, Cukup (C) 60-70, Kurang (D) $<60$. Jadi rentan nilai dalam penilaian hasil belajar siswa yaitu $<60-100$, jika siswa memperoleh nilai kurang dari $>60$ di remedial.

\section{HASIL DAN PEMBAHASAN}

Gambaran Pra Siklus dalam Penelitian tindakan kelas telah dilaksanakan pada semester 2 tahun pelajaran 2019/2020 dengan jumlah siswa sebanyak 14 siswa yang terdiri dari 7 siswa laki-laki dan 7 siswa perempuan, peneliti menggunakan judul "penerapan model konstruktivisme untuk meningkatkan berpikir kritis siswa pada mata pelajaran IPS di kelas V SDN 18 Tubung". Pelaksanaan penelitian ini 
dilakukan dalam dua siklus yang dilaksanakan pada tanggal 8-15 Mei 2019.

Sebelum melakukan penelitian, peneliti terlebih dahulu melakukan observasi terlebih dahulu mengenai pembelajaran yang dilakukan di kelas. Observasi ini dilakuakan untuk mengetahui kondisi awal siswa kelas V SDN 18 Tubung sebelum melakukan penelitian tindakan kelas guna untuk menentukan indikatorindikator yang dicapai. Peneliti juga melakukan wawancara kepada guru kelas $\mathrm{V}$ untuk mencari informasi tentang proses belajar dan berpikir kritis siswa pada mata pelajaran IPS. Berdasarkan hasil observasi siswa kelas $\mathrm{V}$ kurang mengikuti proses pembelajaran. Terlihat ketika guru menjelaskan materi hanya beberapa siswa yang memperhatikan karena siswa sibuk bermain atau ngomong dengan teman sebangkunya. Selain itu guru memberikan pertanyaan kepada siswa, tetapi hanya beberapa siswa aktif yang mampu menjawab. Siswa lebih cenderung teks book ketika menjawab berbagai pertanyaan yang disampaikan guru. Dalam proses pembelajaran guru tidak menggunakan model dan media yang tepat karena guru masih terpacu pada kegiatan-kegiatan yang ada pada buku pegangan guru dan buku pegangan siswa (teks oriented). Dampak dari siswa kurang mengikuti proses pembelajaran yaitu hasil belajar siswa masih rendah yaitu 55,57 serta kurangnya kemampuan siswa dalam mengemukakan pendapat dan menjawab beberapa pertanyaan yang di sampaikan oleh guru selama dalam proses pembelajaran. Selain itu banyak siswa yang mendapatkan nilai di bawah Kriteria Ketuntasan Minimal (KKM) pada mata pelajaran IPS yaitu 60 dan hasil berpikir kritis siswa memperoleh rata-rata nilai 52,23 artinya dari data tersebut berpikir kritis siswa kurang. Dari hal tersebut perlu menggunakan model yang tepat dalam upaya meningkatkan berpikir kritis siswa pada pembelajaran IPS tentang peristiwa kedatangan bangsa barat kelas $\mathrm{V}$ SDN 18 Tubung.

\section{Hasil Penelitian Silkus I}

Perolehan data dari APKG I siklus I pada aspek perencanaan meperoleh rata-rata 3,38 dengan kategori terlaksana (B).Permasalahan yang muncul dalam APKG I dari hasil penilian yaitu (1) kurang menegaskan dalam memberikan apersepsi (2)

Perolehan data dari APKG II siklus I pada aspek pelaksanaan dengan nilai ratarata 3,28 dengan kategori terlaksana (B). Permasalahan yang diperoleh dari APKG II sebagai berikut: (1) kurang menciptakan suasana kondusif dalam pembelajaran (2) kurang menyampaikan langkah-langkah pembelajaran (3) siswa kurang aktif dalam mengungkapkan pendapat pada gambar yang disajikan oleh guru (4) siswa kurang 
mampu menjelaskan dengan bahasa sendiri

(5) siswa kurang mampu menjelaskan hasil diskusi.

Berdasarkan hasil siklus I tentang berpikir siswa pada pembelajaran IPS tentang materi peristiwa kedatangan bangsa barat. Siswayang memperoleh nilai rata-rata yaitu 62.50, dan hasil belajar 67,57 dari hasil penilaian berpikir kritis siswa perlu ada peningkatan bagi siswa yaitu meningkatkan rasa ingin tahu siswa dalam proses pembelajaran dan bagi guru yaitu memotivasi dan memberikan apersepsi pada siswa. Dari hal tersebut perlu upaya peningkatkan berpikir kritis siswa pada pembelajaran IPS tentang peristiwa kedatangan bangsa barat kelas V SDN 18 Tubung pada siklus selanjutnya.

\section{Hasil Penelitian Silkus II}

Dari hasil nilai rata-rata APKG I siklus II pada aspek perencanaan mencapai 3,57 dengan kategori terlaksana (B) artinya RPP yang telah dirancang dapat di gunakan dalam proses pembelajaran.Pada lembar observasi guru (APKG II) siklus II mencapai 3,57.Hasil nilai dari alat penilaian kemampuan guru pada aspek pelaksanaan pembelajaran dengan kategori sangat terlaksana $(\mathrm{A})$.

Berdasarkan hasil observasi pada siklus II tentang berpikir siswa pada pembelajaran IPS tentang materi peristiwa kedatangan bangsa barat. Siswa telah memperoleh nilai rata-rata 80,80 sudah 46 | J P D, p - I S S N : 2252-8156, e - I S S N : $2579-3993$ dikatakan sangat kritis (A)dan hasil siswa dengan nilai rata-rata 77,85 telah mencapai kriteria ketuntasan minimum (KKM) yaitu 60.

\section{SIMPULAN}

Berdasarkan hasil penelitian tindakan kelas yang telah dilaksanakandikelas V SD Negeri 18 Tubung. Peningkatan tersebut dilihat selama proses penelitian dari perencanaan pembelajaran, pelaksanaan pembelajaran, hasil berpikir kritis siswa, dan hasil belajar siswa data hasil penelitian. Dengan menerapkan model konstruktivisme pada mata pelajaran IPS tentang peristiwa kedatangan bangsa barat maka berpikir kritis meningkat. Dari peningkatan tersebut dapat menunjukkan peningkatan sebesar 0,19 pada aspek perencanaan pembelajaran, dalam aspek pelaksanaan aktivitas guru pada siklus II mengalami kenaikan sebesar 0,29 dari siklus sebelumnya. Hal ini terbukti dengan adanya peningkatan hasil berpikir kritis siswa sebesar 18,3 dan hasil balajar meningkat menjadi 10,28.

\section{DAFTAR PUSTAKA}

Aqib, Diniati, Jaiyaroh, Khotimah. 2011. Penelitian Tindakan Kelas. Bandung: CV.Yarama Widya Arikunto. 2010. Prosedur Penelitian Suatu Pendekatan Praktek. Jakarta: Rineka Cipta 
Mahdatika, A. 2013. Penerapan Pendekatan Konstruktivisme Dalam Pembelajaran http://repository.iainpurwokerto.ac.id/ 1192/2/Cover Bab\%20I Bab\%20V Daftar\%20Pustaka.pdf. (Diakses Tanggal 15 Februari 2019)

Purwanto. 2014. Evaluasi Hasil Belajar. Yogyakarta: Pustaka Pelajar
Sapriya. 2017. Pendidkan IPS Konsep dan Pembelajaran. Bandung: PT Remaja Rosdakarya

Susanto, A. 2013. Teori Belajar dan Pembelajaran Di Sekolah Dasar. Jakarta: Kencana Prenadamedia Group.

Trianto. 2013. Mendesain Model Pembelajaran Inovatif-Progresif. Jakarta: Kencana Prenadamedia Group. 